\title{
Penggunaan Ventilasi Mekanik pada Gagal Jantung Akut
}

\author{
Dian Puspita1', Muhammad Fadil²
}

\begin{abstract}
Abstrak
Gagal jantung akut merupakan terminologi yang digunakan untuk mendeskripsikan perubahan yang cepat atau perburukan dari tanda dan gejala gagal jantung. Kondisi ini mengancam kehidupan dan harus ditangani dengan segera. Dilaporkan kasus edema paru akut ec hipertensi emergensi. Diagnosis ditegakkan berdasarkan gejala klinis sesak nafas yang dirasakan tiba-tiba, orthopnea, respiratory distress berat, takipnue, saturasi $\mathrm{O}_{2}$ perifer $<90 \%$, ronkhi basah halus pada seluruh lapang paru. Penanganan yang diberikan adalah pemberian obat vasodilator untuk menurunkan afterload dan pemberian bantuan ventilator untuk mengatasi respiratory distress. Gagal jantung akut merupakan penyebab umum kegagalan pernapasan akut dan sering memerlukan bantuan ventilator. Ventilator noninvasif tekanan positif (CPAP, BiPAP) harus dipertimbangkan pada pasien dengan gangguan pernapasan (frekuensi pernapasan $>25$ napas / menit, $\mathrm{SpO}_{2}<90 \%$ ) dan mulai sesegera mungkin diberikan untuk mengurangi gangguan pernapasan dan mengurangi kejadian intubasi endotrakeal. Jika terjadi kegagalan pernapasan, yang menyebabkan hipoksemia, hypercapnia dan dalam penggunaan ventilator non-invasif maka intubasi endotrakeal dianjurkan.
\end{abstract}

Kata kunci: gagal jantung akut; ventilasi mekanik

\begin{abstract}
Acute heart failure (AHF) is defined as a rapid onset or worsening of symptoms and/or signs of heart failure. It is a life-threatening medical condition requiring urgent treatment. It was reported a case of acute pulmonary edema ec hypertensive emergency. The diagnosis was based on rapid onset of shortness of breath, orthopnea, severe respiratory distress, tachypnoea, peripheral $\mathrm{O} 2$ saturation $<90 \%$, with rales over the lung fields. Management for this patient are vasodilator drugs to reduce afterload and ventilator support to treat respiratory distress. AHF is a common cause of acute respiratory failure and often necessitates ventilatory support. Non-invasive positive pressure ventilation (CPAP, BiPAP) should be considered in patients with respiratory distress (respiratory rate >25 breaths/min, SpO2 $<90 \%$ ) and started as soon as possible in order to decrease respiratory distress and reduce the rate of mechanical endotracheal intubation. Intubation is recommended, if respiratory failure, leading to hypoxaemia, hypercapnia, and acidosis cannot be managed non-invasively.
\end{abstract}

Keywords: acute heart failure; mechanical ventilation

Affiliasi penulis: 1. Program Pendidikan Dokter Spesialis IImu Penyakit Jantung dan Pembuluh Darah, Fakultas Kedokteran, Universitas Andalas, Padang, Indonesia. 2. Bagian Kardiologi dan Kedokteran Vaskular, Fakultas Kedokteran, Universitas Andalas, Padang, Indonesia.

Korespondensi: Bagian Kardiologi dan Kedokteran Vaskular, Fakultas Kedokteran, Universitas Andalas, Padang, Indonesia. Email: kardiologiunand@yahoo.com Telp: 075136494

\section{PENDAHULUAN}

Gagal jantung akut adalah keadaan darurat medis yang paling umum terjadi dan penyebab utama rawat inap yang menyumbang 6,5 juta hari di rumah sakit setiap tahun. Tingkat kematian di rumah sakit pada gagal jantung akut adalah $10 \%$ sampai $20 \%{ }^{1}$ Gagal jantung akut menjadi masalah kesehatan masyarakat yang utama pada beberapa negara industri maju dan Negara berkembang seperti Indonesia. Di Amerika Serikat, gagal jantung akut merupakan penyebab utama lebih dari 1 juta pasien rawat inap per tahun, yang mengakibatkan pengeluaran \$39 miliar per tahun. Angka rawat inap yang sama dilaporkan di Eropa, dengan variasi lama perawatan, tingkat rehospitalisasi, dan kematian. ${ }^{2}$ 
Berdasarkan Pusat Data dan Informasi Kementerian Kesehatan RI tahun 2014, prevalensi penyakit gagal jantung di Indonesia tahun 2013 diperkirakan sekitar 530.068 orang. $^{3}$

Gagal jantung akut merupakan terminologi yang digunakan untuk mendeskripsikan perubahan yang cepat atau perburukan dari tanda dan gejala gagal jantung. Kondisi ini mengancam kehidupan dan harus ditangani dengan segera, dan biasanya berujung pada hospitalisasi. ${ }^{4,5}$ Keadaan pasien dapat berupa kondisi emergensi seperti edema paru akut. ${ }^{5}$

Gagal jantung akut berupa edema paru akut merupakan penyebab umum kegagalan pernapasan akut dan sering memerlukan bantuan ventilator. 4,6 Pemberian ventilasi non-invasif tekanan positif (CPAP, BiPAP) harus dipertimbangkan pada pasien dengan gangguan pernapasan (frekuensi pernapasan > 25 napas / menit, $\mathrm{SpO}_{2}<90 \%$ ) dan mulai sesegera mungkin diberikan untuk mengurangi gangguan pernapasan dan mengurangi kejadian intubasi endotrakeal. Ventilasi non-invasif tekanan positif dapat mengurangi tekanan darah dan harus digunakan dengan hati-hati pada pasien hipotensi. Tekanan darah harus dipantau secara teratur ketika pengobatan ini digunakan. Jika terjadi kegagalan pernapasan, yang menyebabkan hipoksemia $\left(\mathrm{PaO}_{2}<\right.$ $60 \mathrm{mmHg}(8,0 \mathrm{kPa}))$, hypercapnia $\left(\mathrm{PaCO}_{2}>50 \mathrm{mmHg}\right.$ $(6.65 \mathrm{kPa}))$ dan asidosis $(\mathrm{pH}<7,35)$ dalam penggunaan ventilasi non-invasif maka intubasi endotrakeal dianjurkan. ${ }^{4}$

\section{KASUS}

Seorang perempuan hamil usia 30 tahun datang ke IGD RSUP dr. M Djamil Padang dengan keluhan utama sesak nafas dirasakan tiba-tiba sejak 4 jam sebelum masuk rumah sakit. Sesak nafas dirasakan saat pasien sedang istirahat, tidak menciut, tidak dipengaruhi makanan atau cuaca. Sesak bertambah jika pasien berbaring dan berkurang jika pasien dalam posisi duduk atau tegak. Pasien tidak mempunyai riwayat keluhan dyspnea on exertion, paroxysmal nocturnal dyspnea, orthopnea sebelumnya. Sembab di kaki ditemukan sejak 1 minggu terakhir. Nyeri dada disangkal. Pasien mengeluhkan mual dan muntah sebanyak 2 kali berwarna hitam, Tidak ada keluhan berdebar-debar, pingsan, pusing, dan sakit kepala. Pasien saat ini hamil anak kedua, selama kehamilan rutin kontrol ke bidan dan tidak pernah memiliki keluhan seperti saat ini. Riwayat hipertensi selama kehamilan dan diluar kehamilan tidak ada. Keluhan demam dan batuk tidak ada. Pasien kiriman dari RS Ibnu Sina dengan diagnosa edema paru akut + G2P1A0H1 gravida 30 31 minggu + pre-eklampsia berat (PEB) dan telah mendapatkan terapi drip furosemide 2 ampul dalam $\mathrm{RL} 1$ kolf.

Pada pemeriksaan fisik ditemukan keadaan umum berat, kesadaran compos mentis, tekanan darah 190/120 mmHg, nadi $152 \mathrm{x} / \mathrm{m}$ regular, frekuensi nafas $36 \mathrm{x} /$ menit, suhu $37^{\circ} \mathrm{C}, \mathrm{SpO}_{2} 68 \%$ dengan binasal $\mathrm{O}_{2} 4 \mathrm{lpm}$ kemudian 82\% dengan NRM 15 Ipm dan $92-94 \%$ dengan bagging, JVP $5+4 \mathrm{cmH}_{2} \mathrm{O}$. Pada pemeriksaan jantung tidak ditemukan adanya tandatanda pembesaran jantung dan pada auskultasi S1S2 reguler tidak ditemukan murmur dan gallop. Pada pemeriksaan paru ditemukan suara nafas bronkovesikuler, ronki basah halus dan kasar pada seluruh lapang paru, tidak ditemukan wheezing. Pemeriksaan abdomen ditemukan perut membuncit dengan tinggi fundus uteri 3 jari diatas umbilikus. Pemeriksaan ekstremitas ditemukan adanya edema dan akral hangat.

Pada rekaman EKG ditemukan sinus takikardia, QRS rate $150 \mathrm{x} /$ menit, axis normal, gelombang P normal, PR interval 0,16", QRS durasi 0,08", tidak ada ST-T changes, tidak ditemukan hipertrofi ventrikel kiri dan kanan (Gambar 1).

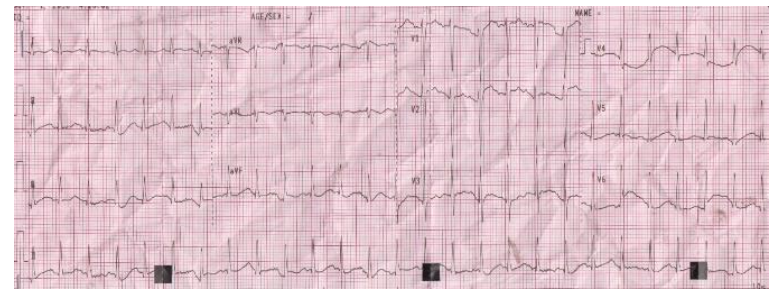

Gambar 1. EKG di IGD pukul 04.20 WIB

Pemeriksaan laboratorium didapatkan hemoglobin 13,4 g/dl, leukosit $25.100 \mathrm{dmm}$, hematokrit $40 \%$, trombosit $335.000 / \mathrm{mm}^{3}$. Dengan elektrolit natrium darah $139 \mathrm{mmol} / \mathrm{L}$, kalium darah 4,6 $\mathrm{mmol} / \mathrm{L}$, klorida darah $117 \mathrm{mmol} / \mathrm{L}$, dan calsium darah 
$8,9 \mathrm{mmol} / \mathrm{L}$, GDS $122 \mathrm{mg} / \mathrm{dl}$, ureum $37 \mathrm{mg} / \mathrm{dl}$, kreatinin 1,3 mg/dl, CCT 60, PT 12,9 detik, aPTT 43 detik INR 1,2 , total protein $4,5 \mathrm{~g} / \mathrm{dl}$, albumin $2,5 \mathrm{~g} / \mathrm{dl}$, globulin 2,0 $\mathrm{g} / \mathrm{dl}$, total bilirubin $0,4 \mathrm{mg} / \mathrm{dl}$, bilirubin । $0,2 \mathrm{mg} / \mathrm{dl}$, bilirubin II 0,2 mg/dl, SGOT $37 \mathrm{U} / \mathrm{l}$, SGPT $13 \mathrm{U} / \mathrm{l}$. Analisa gas darah ditemukan $\mathrm{pH} 6,9, \mathrm{pCO}_{2} 46, \mathrm{pO}_{2} 95$, $\mathrm{HCO}_{3}-9,2, \mathrm{BE}-23,5, \mathrm{SpO}_{2} 90$ dengan kesan asidosis metabolik mixed respiratorik dan hipoksia. Pada Urinalisa ditemukan protein +++.

Pasien didiagnosa dengan edema paru akut ec hipertensi emergensi pada preeclampsia berat, G2P1A0H0 gravida 28-29 minggu, asidosis metabolik mixed asidosis respiratorik, sepsis ec susp community acquired pneumonia, hematemesis ec stress ulcer, dan hipoalbuminemia. Di IGD pasien diberikan terapi bagging, IVFD RL 1 kolf/24jam, furosemid $40 \mathrm{mg}$ iv dilanjutkan dengan drip dosis mulai dari $3 \mathrm{mg} / \mathrm{jam}$, nitrogliserin drip mulai dari $10 \mathrm{mcg} /$ menit, koreksi bicnat 200 meq, dan lansoprazol 80 mg (iv) kemudian lanjut drip $10 \mathrm{mg} / \mathrm{jam}$. Pasien direncanakan dirawat di CVCU, dipasang ventilator non-invasif (NIV) tekanan positif, pemasangan central vena chateter (CVC) , foto thorak, serial AGD, pasang nasal gastic tube (NGT), puasa, dan ekokardiografi.

Pasien dikonsulkan ke bagian Paru, Penyakit Dalam, dan Obgyn. Jawaban dari bagian Obgyn, pasien didiagnosa dengan $\mathrm{G} 2 \mathrm{P} 1 \mathrm{AOH} 1$ gravida preterm 28-29 minggu, fetal distress. Rencana stabilisasi di bagian jantung, terapi sesuai bagian jantung, dan informed consent kondisi janin mengalami perburukan dan kemungkinan tidak bisa diselamatkan. Jawaban konsul dari bagian Penyakit Dalam, pasien didiagnosa dengan hematemesis ec stress ulcer dan dianjurkan puasa dengan NGT alir 8-72 jam, lanjut diet lambung 1 dan bolus lansoprazole $80 \mathrm{mg}$, lanjut drip $10 \mathrm{mg} / \mathrm{jam}$. Sedangkan jawaban konsul dari bagian Paru, pasien didiagnosa sepsis ec community acquired pneumonia dan dianjurkan pemberian meropenem $3 \times 1 \mathrm{gr}$ (iv), levofloxacin $1 \times 750 \mathrm{mg}$ (iv), dexametason $3 \times 2$ amp (tappering off), n-asetil sistein $2 \times 300 \mathrm{mg}$ (iv), dan kultur sputum \& tes sensitivitas kuman banal.

Di CVCU pasien dipasang NIV CPAP dengan setting $\mathrm{FiO}_{2}$ 100\%, PEEP 8, ASB 12 dan didapatkan volum tidal 360-480 cc dengan hasil AGD pH 7,07, $\mathrm{pCO}_{2} 63, \mathrm{pO}_{2} 62, \mathrm{HCO}_{3}-18,3, \mathrm{BE}-11,8, \mathrm{SpO}_{2} 79 \%$ dengan kesan gagal nafas tipe II, asidosis metabolik dan asidosis respiratorik. Pasien gelisah, fatigue, dan tidak kooperatif dengan frekuensi nafas 36x/menit dan $\mathrm{SpO}_{2}$ 80-85\%, sehingga pasien direncanakan untuk dilakukan intubasi endotrakeal dan keluarga setuju. Pasien diintubasi dan disambungkan ke ventilator dengan setting mode inisial IPPV $\mathrm{FiO}_{2} 90 \%$, PEEP 10, RR 16, I:E 1:2, TV set 480 cc. Dilakukan pemeriksaan AGD dengan hasil $\mathrm{pH} 7,08, \mathrm{pCO}_{2} 58, \mathrm{pO}_{2} 93, \mathrm{HCO}_{3}{ }^{-}$ 17,2, $\mathrm{BE}-12,8, \mathrm{SpO}_{2} 93 \%$ dan dilakukan koreksi bicnat sebanyak 125 meq dan optimalkan ventilasi mekanik. Di CVCU pasien diberikan terapi ventilasi mekanik mode IPPV $\mathrm{FiO}_{2}$ 90\%, PEEP 10, RR set 16 , ASB 20, target TV 510 cc, drip morfin-midazolam $2 \mathrm{ml} / \mathrm{jam}$, IVFD RL $500 \mathrm{cc} / 24$ jam, ivelip 2 kolf/24 jam, triofusin E1000 2 kolf/24 jam, drip furosemid $3 \mathrm{mg} / \mathrm{jam}$, drip nitrogliserin $30 \mathrm{mcg} / \mathrm{menit}$, drip lansoprazol 10 $\mathrm{mg} / \mathrm{jam}$, sukralfat $3 \times 10 \mathrm{cc}$, meropenem $3 \times 1 \mathrm{gr}$ iv (skin test), vip albumin $3 \times 1$ kapsul. Pasien direncanakan evaluasi AGD post intubasi, bila memungkinkan ganti mode ventilator ke BiPAP, ekokardiografi, foto thorak post intubasi dan pemasangan CVC, kultur kuman dan tes sensitivitas darah, urin dan sputum.

Pemeriksaan foto thorak post intubasi dan pemasangan CVC ditemukan dengan hasil CTR 54\%, Segmen Aorta dan Segmen Pulmonal normal, pinggang jantung $(+)$, apex tertanam, terdapat infiltrat dan kranialisasi (Gambar 2).

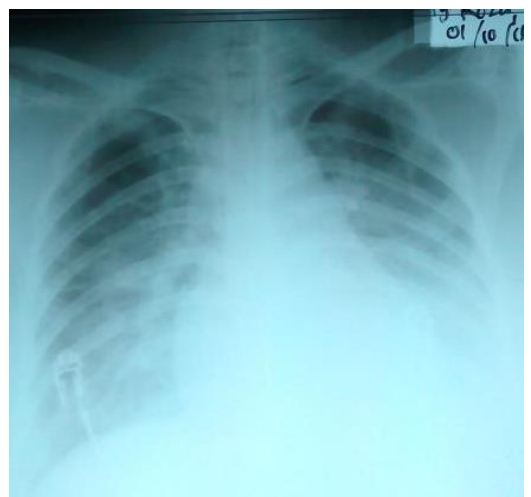

Gambar 2. Foto thorak kasus post intubasi dan pemasangan CVP

Hasil echohemodynamic ditemukan LVOT diameter $2 \mathrm{~cm}$, LVOT VTI $10 \mathrm{~cm}$, SV $31,4 \mathrm{ml}$, CO 4,39 L/menit, SVR 1711 dyne/sec/cm ${ }^{-5}$, eRAP (dari CVP 15 $\mathrm{mmHg}$ ), dan EF $58 \%$ menandakan peningkatan afterload. 
Pukul 08.30 bagian Obgyn melakukan follow up dengan hasil denyut jantung janin (DJJ) 130-135 $\mathrm{x} /$ menit, protein urin ++ dengan kesan fetal distress perbaikan (teresusitasi) pada PEB. Anjuran dari bagian Obgyn yaitu optimalisasi kondisi ibu sambil persiapkan pematangan paru janin, diberikan terapi dexametason 2x2 amp, MgSO4 40\% dalam 500cc (loading dalam 15'), terapi lain sesuai bagian kardiologi. Sikap tim CVCU mengganti sedasi dengan fentanyl drip $1 \mathrm{mcg} / \mathrm{kgbb} / \mathrm{jam}$ karena perbaikan kondisi janin.

Pada pukul 12.00, kondisi pasien perbaikan dengan pengaturan ventilator $\mathrm{BiPAP}, \mathrm{FiO}_{2} 90 \%$, Pins 15, Pasb 10, PEEP 8, RR 10 dengan hasil analisa gas darah $\mathrm{pH} 7,40, \mathrm{pCO}_{2} 30, \mathrm{pO}_{2} 81, \mathrm{HCO}_{3}^{-}$18,8, $\mathrm{BE}-6,2$, $\mathrm{SpO}_{2}$ 96\%. Jika kondisi pasien stabil akan dilakukan weaning perlahan. Pada pukul 14.00, pasien gelisah dengan tekanan darah $161 / 91 \mathrm{mmHg}$, denyut jantung $138 \mathrm{x} /$ menit, $\mathrm{SpO}_{2} 88-91 \%$, diuresis $1.1 \mathrm{cc} / \mathrm{kgbb} / \mathrm{jam}$, dan pemeriksaan paru ditemukan ronki basah di $1 / 3$ basal paru. Kesan pasien mengalami impending Acute Lung Oedema. Ventilator diganti pengaturannya menjadi IPPV $\mathrm{FiO}_{2}$ 90\%, TV 450, RR 16, PEEP 10. Hasil AGD 2 jam setelah penggunaan IPPV pH 7,33, $\mathrm{pCO}_{2}$ 37, $\mathrm{pO}_{2}$ 82, $\mathrm{HCO}_{3}-18,9, \mathrm{BE}-6,0, \mathrm{SpO}_{2}$ 94\%. Rencana akan dilakuan penurunan setting ventilator bertahap dan AGD ulang besok pagi. Terapi furosemide dinaikkan menjadi $5 \mathrm{mg} / \mathrm{jam}$.

Pada Pukul 17.00 bagian Obgyn melakukan follow up dengan hasil DJJ dan gerak janin dari USG tidak ada, dengan kesan IUFD. Sikap tim CVCU mengganti sedasi dengan morfin-midazolam 2cc/jam dan optimalisasi terapi.

Pada hari rawatan kedua, pasien dalam pengaruh obat sedasi. Pemeriksaan fisik ditemukan tekanan darah 123/78 $\mathrm{mmHg}$, denyut jantung 111 $\mathrm{x} /$ menit, suhu $37,2^{\circ} \mathrm{C}$, diuresis $1,4 \mathrm{cc} / \mathrm{kgbb} / \mathrm{jam}$, dan pemeriksaan paru ditemukan bronkovesikuler, ronki kasar, wheezing tidak ada. Pada pemeriksaan laboratorium ditemukan perbaikan leukosit $20.500 / \mathrm{mm}^{3}$. Hasil AGD dengan pengaturan ventilator IPPV/VCV $\mathrm{FiO}_{2}$ 80\%, TV 450, RR 12, PEEP 10 yaitu $\mathrm{pH} 7,30, \mathrm{pCO}_{2} 25, \mathrm{pO}_{2} 81, \mathrm{HCO}_{3}^{-}$15,2, $\mathrm{BE}-14,2, \mathrm{SpO}_{2}$ $94 \%$. Ventilator diganti pengaturan menjadi mode SIMV $\mathrm{FiO}_{2} 70 \%$, volum tidal 450, Pasb 10, PEEP 10,
RR 6. AGD 1 jam setelah penggantian mode SIMV $\mathrm{pH}$ 7,39, $\mathrm{pCO}_{2} 31, \mathrm{pO}_{2}$ 207, $\mathrm{HCO}_{3}^{-}$18,8, BE -6,2, $\mathrm{SpO}_{2}$ $100 \%$ dan ventilator diganti pengaturannya menjadi CPAP ASB $\mathrm{FiO}_{2} 70 \%$, PEEP 10, Pasb 15. Terapi dilanjutkan dan ditambah ramipril $1 \times 2,5 \mathrm{mg}$. Antibiotik meropenem $3 \times 1$ gram (iv), levofloxacin $1 \times 750 \mathrm{mg}$ (iv).

Pada Hari rawatan ketiga, kondisi pasien mengalami perbaikan. Pemeriksaan fisik ditemukan tekanan darah $138 / 90 \mathrm{mmHg}$, denyut jantung 99 $\mathrm{x} /$ menit, suhu $37,2^{\circ} \mathrm{C}$, diuresis $1,2 \mathrm{cc} / \mathrm{kgbb} / \mathrm{jam}$ dilakukan pemeriksaan AGD dengan hasil $\mathrm{pH} 7,41$, $\mathrm{pCO}_{2} 35, \mathrm{pO}_{2}$ 194, $\mathrm{HCO}_{3}-22,2, \mathrm{BE}-2,4, \mathrm{SpO}_{2} 100 \%$ dan ventilator diganti pengaturannya menjadi CPAP ASB $\mathrm{FiO}_{2} 70 \%$, PEEP 8, Pasb 10. Terapi dilanjutkan, obat sedasi diturunkan dosis morfin-midazolam 0,5 cc/jam, ramipril $2 \times 2,5 \mathrm{mg}$

Pada hari rawatan keempat, kondisi pasien mengalami perbaikan, pasien sadar dan kooperatif. Pemeriksaan fisik ditemukan tekanan darah 132/85 $\mathrm{mmHg}$, denyut jantung $92 \mathrm{x} /$ menit, suhu $36.8^{\circ} \mathrm{C}$, diuresis $1,35 \mathrm{cc} / \mathrm{kgbb} / \mathrm{jam}$ dilakukan pemeriksaan AGD dengan hasil $\mathrm{pH} 7,37, \mathrm{pCO}_{2} 44, \mathrm{pO}_{2}$ 160, $\mathrm{HCO}_{3}^{-}$25,4, $\mathrm{BE} 0,1, \mathrm{SpO}_{2} 99 \%$ dan pengaturan ventilator menjadi CPAP ASB $\mathrm{FiO}_{2} 60 \%$, PEEP 8, Pasb 10. Obat nitrogliserin iv dihentikan, dosis ramipril $2 \times 5 \mathrm{mg}$.

Pada hari rawatan kelima, kondisi pasien stabil, sadar, dan kooperatif. Pemeriksaan fisik ditemukan tekanan darah $138 / 785 \mathrm{mmHg}$, denyut jantung 90 $\mathrm{x} /$ menit, suhu $36.8^{\circ} \mathrm{C}$, diuresis $1,2 \mathrm{cc} / \mathrm{kgbb} / \mathrm{jam}$ dilakukan pemeriksaan AGD dengan hasil $\mathrm{pH} 7,51$, $\mathrm{pCO}_{2}$ 31, $\mathrm{pO}_{2}$ 205, $\mathrm{HCO}_{3}{ }^{-} 24,7, \mathrm{BE} 1,7, \mathrm{SpO}_{2} 100 \%$ dan pengaturan ventilator menjadi CPAP $\mathrm{FiO}_{2} 50 \%$, PEEP 5. Rencana weaning CPAP ke T-piece. Pukul 12.00, kondisi pasien perbaikan, TD 134.72, denyut jantung $90 \mathrm{x} /$ menit, suhu $36,7^{\circ} \mathrm{C}$, pasien dilakukan ekstubasi.

Pada hari rawatan keenam, kondisi pasien stabil, keadaan umum ringan, kesadaran komposmentis kooperatif, ditemukan tekanan darah $128 / 75 \mathrm{mmHg}$, denyut jantung $90 \mathrm{x} /$ menit, frekuensi nafas $16 \mathrm{x} /$ menit, $\mathrm{SpO} 298 \%$, suhu $36.8^{\circ} \mathrm{c}$, diuresis $1,1 \mathrm{cc} / \mathrm{kgbb} / \mathrm{jam}$. Hasil AGD pH 7,51, $\mathrm{pCO}_{2} 29, \mathrm{pO}_{2}$ 178, $\mathrm{HCO}_{3}-23,1, \mathrm{BE} 0,3, \mathrm{SpO}_{2} 100 \%$ Pasien pindah ke bangsal obgyn untuk dilakukan terminasi. 


\section{PEMBAHASAN}

Pada kasus ini, pasien didiagnosis dengan edema paru akut ec hipertensi emergensi. Diagnosis ditegakkan berdasarkan gejala klinis sesak nafas dirasakan tiba-tiba beberapa jam sebelum masuk rumah sakit, timbul saat pasien istirahat dan bertambah berat jika pasien berbaring dan berkurang jika pasien dalam posisi duduk atau tegak (orthopnea) yang merupakan gejala tipikal dari gagal jantung. Pada pemeriksaan fisik ditemukan tanda yang mengarah ke edema paru akut karena pada pasien ditemukan keadaan umum berat, frekuensi nafas $>25$ $\mathrm{x}$ / menit, saturasi $\mathrm{O}_{2}$ perifer < $90 \%$, peningkatan JVP. Pada pemeriksaan paru ditemukan ronkhi basah halus pada seluruh lapang paru. Pada rontgen thorax ditemukan adanya kranialisasi.

Gagal jantung akut merupakan terminologi yang digunakan untuk mendeskripsikan perubahan yang cepat atau perburukan dari tanda dan gejala gagal jantung (tabel 1).4,5

Tabel 1. Gejala dan tanda dari gagal jantung ${ }^{4}$

\begin{tabular}{|c|c|}
\hline Gejala & Tanda \\
\hline Tipikal & Lebih spesifik \\
\hline Sesak & $\begin{array}{l}\text { Peningkatan tekanan } \\
\text { vena jugular }\end{array}$ \\
\hline Ortopnea & Refluk hepatojugular \\
\hline $\begin{array}{l}\text { Paroxymal nocturnal } \\
\text { dyspnea }\end{array}$ & Suara $S_{3}$ \\
\hline $\begin{array}{l}\text { Lelah, capek, } \\
\text { membutuhkan waktu } \\
\text { yang lama untuk } \\
\text { pemulihan setelah } \\
\text { latihan fisik }\end{array}$ & $\begin{array}{l}\text { Perpindahan impuls } \\
\text { apikal jantung ke lateral }\end{array}$ \\
\hline \multicolumn{2}{|l|}{ Pembengkakan kaki } \\
\hline Sedikit tipikal & Sedikit Spesifik \\
\hline Batuk pada malam hari & $\begin{array}{l}\text { Penambahan berat } \\
\text { badan ( }>2 \mathrm{~kg} / \mathrm{minggu})\end{array}$ \\
\hline Mengi & Penurunan berat badan \\
\hline Perasaan kembung & Kaheksia \\
\hline Penurunan nafsu makan & Murmur jantung \\
\hline $\begin{array}{l}\text { Konfusio (terutama usia } \\
\text { tua) }\end{array}$ & Edema perifer \\
\hline Depresi & Krepitasi pulmonal \\
\hline Palpitasi & Efusi pleura \\
\hline Pusing & Takikardia \\
\hline Sinkop & Nadi irreguler \\
\hline \multirow[t]{7}{*}{ Bendopnea } & Takipnea \\
\hline & Respirasi cheyne stokes \\
\hline & Hepatomegali \\
\hline & Asites \\
\hline & Ektremitas dingin \\
\hline & Oliguri \\
\hline & Tekanan nadi sempit \\
\hline
\end{tabular}

Pasien dengan gagal jantung akut biasanya akan hadir dengan salah satu dari enam klasifikasi klinis. Edema paru akut dapat menjadi komplikasi dari klasifikasi klinis tersebut. Dari gambar 3 dapat dilihat adanya overlap antara masing-masing klasifikasi klinis. Enam klasifikasi klinis gagal jantung akut yaitu: ${ }^{2}$

1. Worsening or decompensated chronic Heart Failure

Biasanya ada riwayat memburuknya gagal jantung kronis yang sudah dikenal atau dalam pengobatan secara progresif, dan adanya bukti kongesti sistemik dan paru.

2. Edema paru akut

Pasien datang dengan respiratory distress, takipnea, dan ortopnu dengan ronkhi yang memenuhi paru-paru. Saturasi arteri $\mathrm{O} 2$ biasanya $<90 \%$ pada ruang udara sebelum pengobatan dengan oksigen.

3. Gagal jantung hipertensi

Tanda-tanda dan gejala gagal jantung disertai dengan tekanan darrah yang tinggi dan biasanya fungsi LV sistolik baik. Adanya bukti peningkatan tonus simpatik dengan takikardia dan vasokonstriksi. Pasien mungkin euvolemik atau hanya sedikit hypervolemik, dan sering dengan tanda-tanda kongesti paru tanpa tanda-tanda kongesti sistemik.

4. Syok kardiogenik

Didefinisikan sebagai hipoperfusi jaringan akibat gagal jantung setelah koreksi dari preload yang memadai dan aritmia. Tidak ada parameter diagnostik hemodinamik. Namun, biasanya, syok kardiogenik ditandai dengan tekanan darah sistolik yang rendah (tekanan darah sistolik $<90 \mathrm{mmHg}$ atau penurunan tekanan arteri rata $>30 \mathrm{mmHg}$ ) dan tidak adanya atau rendah pengeluaran urin $(<$ $0,5 \mathrm{~mL} / \mathrm{kg} / \mathrm{jam})$.

5. Gagal jantung kanan terisolasi

Ditandai dengan low output syndrome dengan tidak adanya kongesti paru dengan peningkatan tekanan vena jugularis, dengan atau tanpa hepatomegali, dan tekanan pengisian LV yang rendah.

6. Sindrom koroner akut dan gagal jantung Banyak pasien dengan gagal jantung akut hadir akibat sindrom koroner akut (sekitar 15\%) 
Penyebab gagal jantung akut pada kasus adalah hipertensi emergensi dimana tekanan darah pasien > 180/120 mmHg. Hipertensi emergensi merupakan krisis hipertensi dimana tekanan darah sistolik > $180 \mathrm{mmHg}$ dan tekanan darah diastolik > $120 \mathrm{mmHg}$ dengan disertai adanya keterlibatan kerusakan target organ seperti edema paru akut. ${ }^{7}$

Gagal jantung akut dapat berupa gagal jantung yang baru terjadi pertama kali (de novo ) dan gagal jantung dekompensasi akut pada gagal jantung kronis yang sebelumnya stabil,dan mungkin disebabkan oleh disfungsi jantung primer atau dipresipitasi oleh beberapa faktor seperti infeksi, hipertensi tidak terkontrol, gangguan irama atau ketidakpatuhan dengan obat atau diet. ${ }^{4,5}$. Pada kasus ini dipresipitasi oleh infeksi dan gangguan metabolik atau hormonal seperti kehamilan.

Gagal jantung akut adalah kondisi medis yang mengancam jiwa yang membutuhkan pengobatan segera (Gambar 4). Pasien dengan respiratory distress atau hemodinamik tidak stabil harus diprioritaskan dan membutuhkan respiratory and cardiovascular support. Pada kasus pasien mengalami respiratory distress terlihat dari frekuensi nafas $>25$ nafas/menit, $\mathrm{SpO}_{2}<90 \%$ sehingga membutuhkan ventilasi non-invasif tekanan positif (CPAP, BiPAP) sesegera mungkin untuk mengurangi respiratory distress, mengurangi kejadian intubasi endotrakeal, dan angka kematian (tabel 3). ${ }^{1,4,8-11}$ Ventilasi noninvasif tekanan positif dapat mengurangi tekanan darah dan harus digunakan dengan hati-hati pada pasien hipotensi. Tekanan darah harus dipantau secara teratur ketika pengobatan ini digunakan. Jika terjadi kegagalan pernapasan, yang menyebabkan hipoksemia $\left(\mathrm{PaO}_{2}<60 \mathrm{mmHg}(8,0 \mathrm{kPa})\right)$, hypercapnia $\left(\mathrm{PaCO}_{2}>50 \mathrm{mmHg}(6.65 \mathrm{kPa})\right)$ dan asidosis $(\mathrm{pH}$ $<7,35)$ dalam penggunaan ventilasi non-invasif maka intubasi endotrakeal dianjurkan. ${ }^{4}$

Tujuan utama dari bantuan ventilasi mekanik adalah memperbaiki gangguan oksigenasi dan membantu ventilasi alveolar sehingga karbon dioksida $\left(\mathrm{CO}_{2}\right)$ eliminasi. Jika dilakukan intubasi trakea maka istilahnya disebut ventilasi invasif, sedangkan ventilasi non-invasif (NIV) digunakan pada ventilasi tanpa intubasi trakea dan melalui masker. ${ }^{12}$

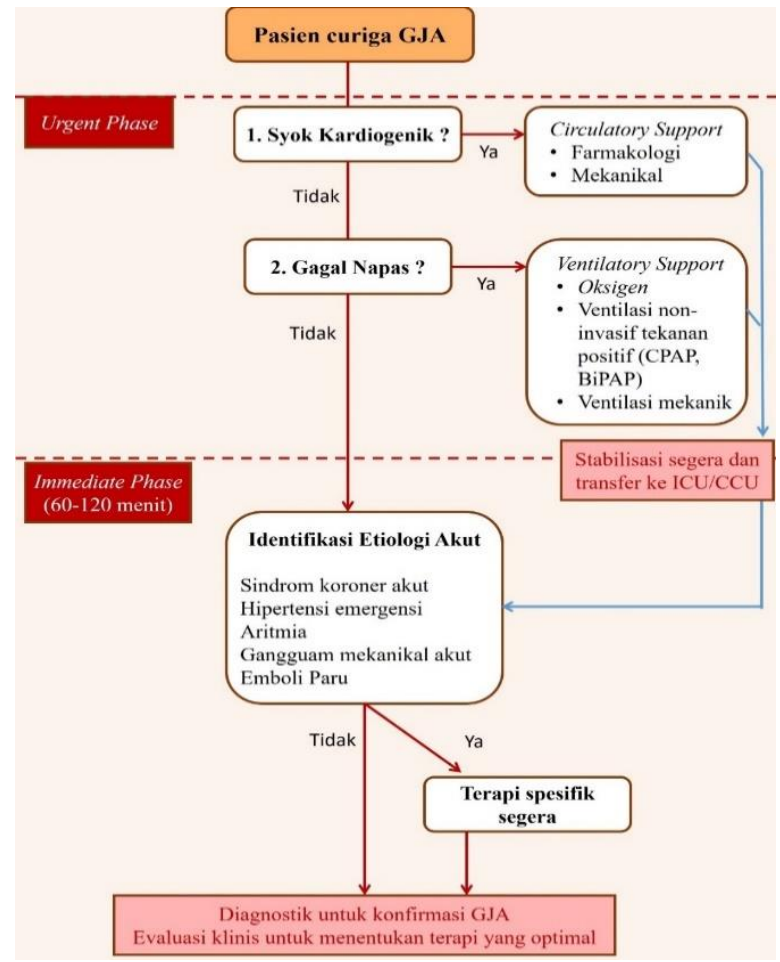

Gambar 3. Managemen awal pada gagal jantung akut $^{4}$

Beberapa studi menyatakan bahwa NIV CPAP memperbaiki oksigenasi, menurunkan work of breathing, dan meningkatkan curah jantung pada pasien gagal jantung akut. ${ }^{12,13}$ Ventilasi non invasif CPAP membantu pasien gagal jantung akut melalui beberapa mekanisme yang dapat memperbaiki masalah pernapasan dan hemodinamik. Ventilasi non invasif CPAP memperbaiki masalah pernapasan dengan menurunkan atelektasis dan tekanan hidrostatik yang menyebabkan edema paru. Atelektasis umum terjadi pada pasien gagal jantung akut. Pembesaran ventrikel kiri mengakibatkan kurangnya ruang untuk lobus kiri bawah di dada. Selain itu, pasien sering tidak bergerak karena penyakit mereka dan ditempatkan di semi - posisi telentang. Ini meningkatkan kemungkinan terjadinya atelektasis lobus kiri bawah paru, karena banyak dari lobus ini terletak posterior dari jantung. Ventilasi non invasif CPAP meningkatkan tekanan positif di alveoli sepanjang siklus pernapasan, sehingga mencegah terjadinya atelektasis. ${ }^{13}$

Persamaan Starling force menggambarkan kekuatan yang mempengaruhi efflux cairan melewati dinding kapiler. Persamaannya: $Q=K[(P p c-P p i)-$ 
(трс - трі)], dimana Q merupakan laju filtrasi cairan di membrane kapiler paru , $\mathrm{K}$ adalah koefisien filtrasi endothelium, Ppc adalah tekanan hidrostatik kapiler paru, Ppi adalah tekanan hidrostatik interstisium paru, трс adalah tekanan onkotik plasma kapiler paru, dan прі adalah tekanan onkotik plasma interstisium paru. ${ }^{12,13}$ Ventilasi non invasif CPAP meningkatkan tekanan dalam alveoli dan beberapa tekanan ini ditransfer ke interstitium dari alveoli, sehingga pergerakan cairan dari kapiler ke interstitium berkurang, sehingga mengurangi laju filtrasi. Ventilasi non invasif CPAP juga membantu pasien gagal jantung akut dengan mengurangi afterload pada ventrikel kiri dengan menurunkan tekanan darah sistolik. Karena penurunan afterload tidak disertai dengan penurunan preload maka curah jantung meningkat. ${ }^{13}$

Ketidakseimbangan persamaan starling force mengakibatkan edema paru akut. Jika tekanan atrium kiri melebihi $20 \mathrm{cmH} 2 \mathrm{O}$, tekanan hidrostatik kapiler paru meningkat, menyebabkan akumulasi cairan di interstitium dan ruang alveolar. ${ }^{12}$

Ventilasi non invasif BiPAP meningkatkan jumlah ventilasi permenit dan ini sangat berguna pada pasien dengan hiperkapnia, seperti pasien PPOK. ${ }^{4}$ Pada beberapa studi, peneliti membandingkan CPAP dengan BiPAP dan menemukan bahwa BiPAP lebih efektif dan cepat memperbaiki ventilasi, cardiac performance, dan tanda-tanda vital dibandingkan CPAP pada pasien edema paru akut, tetapi angka infark miokard lebih tinggi dibandingkan CPAP. ${ }^{14}$ Namun pada penelitian dan tinjauan sistematis lainnya, sampai saat ini tidak ada yang mendukung penyataan BiPAP meningkatkan angka infark miokard $^{12}$ dan tidak ada perbedaan hasil yang signifikan jika dibandingkan penggunaan BiPAP maupun CPAP pada pasien edema paru akut. ${ }^{12,15}$

Pada kasus, pasien diberikan CPAP, namun pasien gelisah dan tidak kooperatif sehingga respiratory distress tidak mengalami perbaikan dan work of breathing meningkat. Pasien mulai fatigue, letargi, $\mathrm{SpO}_{2}<90 \%$, dan hasil $\mathrm{AGD}$ masih ditemukan hipoksia mengakibatkan pasien harus dilakukan intubasi endotrakeal (gambar 6).4,13,16

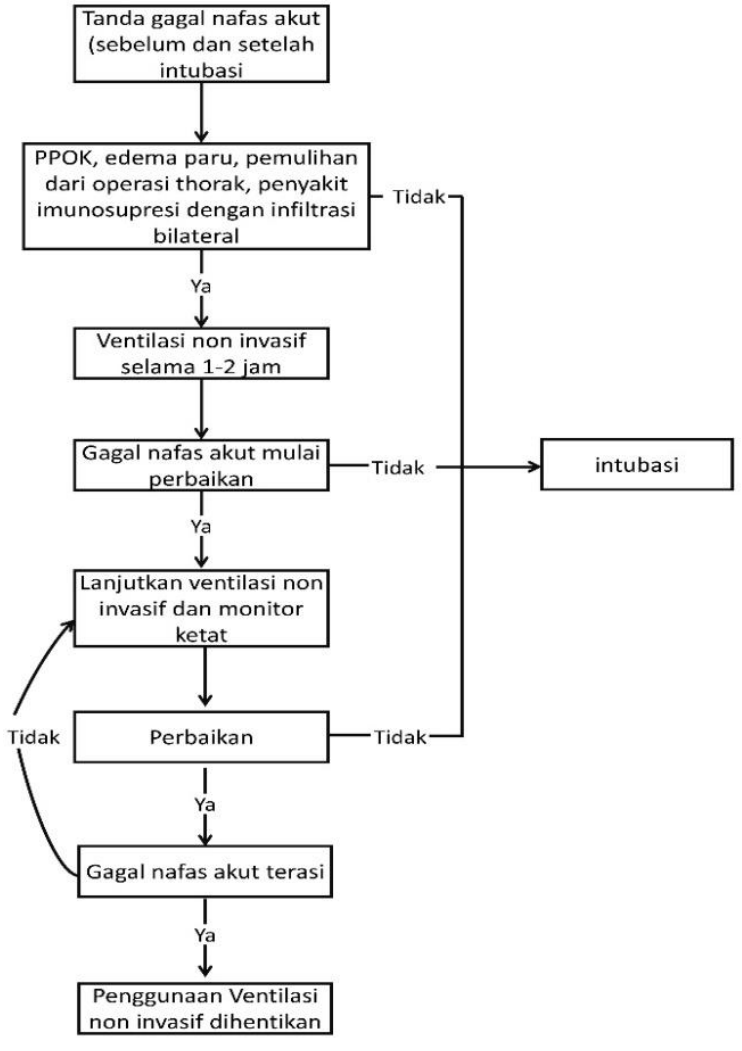

Gambar 4. Algoritma intubasi pada pengunaan NIV ${ }^{13}$

Pasien sakit kritis seperti pada kasus sering tidak nyaman karena rasa sakit, kecemasan, dan keengganan untuk menjalani ventilasi invasif. Ketidaknyamanan ini dapat dibantu dengan pemberian sedasi terus menerus, biasanya di kombinasi dengan opioid pada dosis rendah. Obat opioid yang dipilih pada kasus adalah morfin sedangkan obat sedasi yang digunakan adalah midazolam. Morfin adalah opioid tertua yang digunakan saat ini. Opioid tetap merupakan obat andalan untuk terapi analgetik pada pasien ventilator. Opioid memiliki efek hemodinamik minimal pada pasien euvolemik. ${ }^{17}$ Pada kasus, awalnya pasien mengalami fetal distress dan kemungkinan janin tidak selamat, sehingga diberikan morfin. Namun setelah diberikan terapi, janin mengalami perbaikan dan analgetik yang diberikan kepada ibu adalah fentanyl. Fentanyl adalah opioid sintetik 1000 kali lebih kuat dari petidin dan memiliki efek durasi yang relatif singkat, namun memiliki efek samping khas opioid. ${ }^{18}$ Fentanyl sering digunakan pada analgesia obstetrik karena denyut jantung janin tidak berubah secara signifikan dengan fentanyl. ${ }^{18}$ 
Benzodiazepin yang paling umum digunakan untuk sedasi adalah midazolam dan lorazepam. Midazolam bekerja cepat, larut dalam air yang diekskresikan dalam urin. Sedangkan lorazepam merupakan benzodiazepine long acting yang dimetabolisme di hati dan diekskresikan melalui ginjal. Selama pemberian infus jangka pendek, midazolam dan lorazepam merupakan sedasi yang aman dan efektif. Namun lorazepam dosis tinggi dapat memberikan efek toksisitas sehingga harus dipertimbangkan penggunaannya pada pasien asidosis metabolik, hiperosmolaritas, dan klinis yang mengalami perburukan. Lorazepam merupakan faktor risiko independent pasien mengalami delirium, ${ }^{17}$ sehingga lebih baik menggunakan sedasi midazolam seperti yang diberikan pada kasus. Benzodiazepin menyebrangi plasenta, ${ }^{19}$ namun hubungan antara paparan benzodiazepin selama kehamilan dan kelainan kongenital pada bayi masih kontroversial, dan literatur yang tersedia saling bertentangan. Namun jika pasien hamil sakit kritis membutuhkan benzodiazepin saat kehamilan harus diberikan. ${ }^{20}$ Untuk meminimalkan risiko yang mungkin dapat terjadi pada janin, maka benzodiazepine diberikan dalam dosis rendah. ${ }^{19}$

Saat ini belum ada bukti dari perbaikan hasil pada pasien terkait dengan penggunaan mode ventilasi invasif tertentu. ${ }^{12,21}$ Secara khusus, sampai saat ini tidak ada uji coba terkontrol yang mempelajari pengaruh mode ventilasi invasif yang berbeda pada pasien dengan gagal jantung. Pada kasus, ventilator yang digunakan pada awalnya adalah kontrol volum. Ventilator dengan mode kontrol volum merupakan mode ventilator ideal yang diberikan pada pasien dalam penyakit krisis akut dan bertujuan untuk menyediakan ventilasi yang adekuat dengan mengistirahatkan usaha nafas pada pasien. ${ }^{13}$ Setelah perbaikan ventilasi invasif yang diberikan adalah BiPAP. Mode pressure support ventilator seperti CPAP, SIMV, BiPAP dapat melindungi paru dari barotrauma dan memungkinkan terjadinya nafas spontan pada pasien. Ada keuntungan hemodinamik yang terkait dengan mode ventilasi yang memungkinkan aktivitas pernafasan spontan. Mereka cenderung menghasilkan tekanan jalan nafas rata-rata dan tekanan intrapleural lebih rendah terhadap volume menit yang diberikan, dibandingkan dengan mode yang dikendalikan sepenuhnya oleh ventilasi. ${ }^{12}$

Penghentian penggunaan ventilasi mekanik harus dilakukan sesegera mungkin setelah gangguan jantung yang menyebabkan gangguan ventilasi stabil. Weaning ventilasi mekanis merupakan elemen penting dan universal dalam perawatan pasien kritis yang diintubasi. $^{22}$ Istilah weaning digunakan untuk menggambarkan transisi dari bantuan penggunaan ventilator sepenuhnya ke pernafasan spontan atau pernafasan yang tidak dibantu ventilator. ${ }^{12,23}$

Setelah penyakit dasar teratasi, harus dilakukan penilaian terhadap kesiapan pasien untuk dilakukan penghentian bantuan ventilasi. Penilaian ini biasanya terjadi selama spontaneous breathing trial (SBT). Penilaian SBT membutuhkan pasien untuk bernapas sepenuhnya tanpa bantuan (T-piece terhubung ke endotrakeal tube) atau dengan CPAP dan / atau dukungan tekanan inspirasi yang rendah. Percobaan SBT biasanya berlangsung selama 30 menit dan selama itu pasien dipantau secara ketat dengan menilai tanda-tanda ketidaknyamanan, work of breathing yang meningkat, dan ketidakstabilan hemodinamik. ${ }^{12}$

Ada 3 kategori pasien berdasarkan proses weaning :22

1. Kelompok simple weaning

Merupakan pasien yang langsung berhasil lulus SBT dan diekstubasi tanpa kesulitan. Prognosis kelompok ini baik, dengan mortalitas ICU sekitar $5 \%$.

\section{Kelompok difficult weaning}

Merupakan pasien yang gagal weaning pertama membutuhkan sampai tiga SBT atau selama 7 hari dari SBT pertama untuk mencapai weaning yang sukses.

\section{Kelompok prolonged weaning}

Merupakan pasien yang membutuhkan lebih dari tiga SBT atau $>7$ hari weaning setelah SBT pertama.

Pada kasus dikategorikan kelompok simple weaning karena pada pasien dilakuan SBT pertama kali dan tidak mengalami kegagalan dan diekstubasi tanpa 
kesulitan. Alasan kasus dapat dilakukan weaning segera adalah penanganan yang tepat dalam menurunkan afterload dan tidak ditemukan adanya disfungsi LV dan PPOK.

\section{DAFTAR PUSTAKA}

1. Weng CL, Zhao YT, Liu QH, Fu CJ, Sun F, Ma $\mathrm{YL}$, et al. Meta-analysis: noninvasive ventilation in acute cardiogenic pulmonary edema. Ann Intern Med. 2010;152: 590-600.

2. Gheorghiade M, Filippatos GS, Felker GM. Diagnosis and management of acute heart failure syndromes. In: braunwald's heart disease: a textbook of cardiovascular medicine, $9^{\text {th }}$ ed. Philadelphia: Elsevier Saunders. 2012; 27.p. 517-42.

3. Pusat Data dan Informasi Kementerian Kesehatan RI tahun 2014. Jakarta: Kementerian Kesehatan RI.

4. Ponikowski P, Voors AA, Anker SD, Bueno $\mathrm{H}$, Cleland JG, Coats AJ, et al. ESC guidelines for the diagnosis and treatment of acute and chronic heart failure. European Heart Journal. 2016; 37: 2129-200.

5. Dickstein K, Cohen A, Filippatos G, McMurray JJ, Ponikowski P, Poole PA, et al. ESC guidelines for the diagnosis and treatment of acute and chronic heart failure. European Heart Journal. 2008; 29: 2388-2442.

6. Mehta Sangeeta, Al-Hashim AH, Keenan SP. Noninvasive ventilation in patients with acute cardiogenic pulmonary edema. Respir Care. 2009;54(2):186 -95.

7. Chobanian AV, Bakris GL, Black HR, Cushman WC, Green LA, Izzo JL, et al. Seventh report of the joint national committee on prevention, detection, evaluation, and treatment of high blood pressure. Hypertension. 2003;42:1206-52.

8. Gray AJ, Goodacre S, Newby DE, Masson MA, Sampson F, Dixon S, Crane S, Elliott M, Nicholl J. A multicentre randomised controlled trial of the use of continuous positive airway pressure and non-invasive positive pressure ventilation in the early treatment of patients presenting to the emergency department with severe acute cardiogenic pulmonary oedema: the 3CPO Trial. Health Technol Assess. 2009;13:1-106.

9. Vital FMR, Ladeira MT, Atallah AN. Non-invasive positive pressure ventilation (CPAP or bilevel NPPV) for cardiogenic pulmonary oedema. Cochrane Database Syst Rev. 2013; 5.

10. Park M, Sangean MC, Volpe MDS, Feltrim MIZ, Nozawa E, Leite PF, et al. Randomized, prospective trial of oxygen, continuous positive airway pressure, and bilevel positive airway pressure by face mask in acute cardiogenic pulmonary edema. Crit Care Med. 2004; 32: 2407-15.

11. Gray A, Goodacre S, Newby DE, Masson M, Sampson F, Nicholl J, et al. Noninvasive ventilation in acute cardiogenic pulmonary edema. N Engl J Med. 2008; 359:142-51.

12. Corredor Carlos, Jaggar SI. Ventilator management in the cardiac intensive care unit. Cardiol Clin. 2013; 619-36.

13. Grinnan DC, Truwit JD. Noninvasive ventilation in acute CHF. In: A practical guide to mechanical ventilation, $1^{\text {st }}$ ed. John Wiley \& Sons. 2011.p. 41-50.

14. Chadda K, Annane D, Hart N, Gajdos P, Raphaël JC, Lofaso F. Cardiac and respiratory effects of continuous positive airway pressure and noninvasive ventilation in acute cardiac pulmonary edema. Crit Care Med. 2002 Nov; 30(11): 2457-61.

15. Li H, Hu C, Xia J, Li X, Wei H, Zeng X, et al. A comparison of bilevel and continuous positive airway pressure noninvasive ventilation in acute cardiogenic pulmonary edema. Am J Emerg Med. 2013 Sep; 31(9):1322-7.

16. Mebazaa A, Yilmaz MB, Levy P, Ponikowski P, Peacock WF, Laribi S, et al. Recommendations on pre-hospital and early hospital management of acute heart failure: a consensus paper from the HFA of the ESC, the European Society of Emergency Medicine and the Society of Academic Emergency Medicine. Eur J Heart Fail. 2015;17: 544-58.

17. Gommers D, Bakker J. Medications for analgesia and sedation in the intensive care unit: an overview. Critical Care. 2008; 12 (Suppl 3): S4 
18. Aronson JK. Opioid receptor agonists and antagonists. In: Meyler's side effects of analgesics and anti-inflammatory drugs. Elsevier B.V. 2010;1:1-164.

19. Baird SM, Krau SD, Belfort MA. Pharmacologic Agents. In: High-risk and criticall care obstetric, $3^{\text {rd }}$ ed. Lippincott Williams \& Wilkins. 2013; 6: 60-108.

20. Pacheco LD, Saade GR, Hankins GD. Mechanical ventilation during pregnancy: sedation, analgesia, and paralysis. Clinical obstetrics and gynecology. 2014;57(4):844-50
21. Gonzalez M, Arroliga AC, Frutos-Vivar F, Raymondos K, Esteban A, Putensen C, et al. Airway pressure release ventilation versus assistcontrol ventilation: a comparative propensity score and international cohort study. J Intensive Care Med. 2010; 36(5): 817-27.

22. Boles JM, Bion J, Connors A, Herridge M, Marsh $\mathrm{B}$, Melot $\mathrm{C}$, et al. Weaning from mechanical ventilation. Eur Respir J. 2007;29:1033-56.

23. McConville JF, Kress JP. Weaning patients from the ventilator. N Engl J Med. 2012; 367 (23): 2233-9. 